complex with vitamin $\mathrm{C}$ increases adaptive ability of the sows and their newborn piglets. These supplements characterized by antistress modulating properties and prolonged effect.

Key words: sows, piglets, critical periods of ontogenesis, adaptive ability of organism, «Humilid», ascorbic acid.

Стаття надійшла до редколегії 28.01.2015 p.

УДК 57.044:[616.018:616.348-022]

\author{
Марина Єна, \\ Галина Кузнєцова, \\ Наталія Дзюбенко, \\ Володимир Рибальченко
}

\title{
Вплив похідних піролу на слизову оболонку товстої кишки щурів, порівняно з глюкокортикоїдним препаратом, за умов розвитку експериментального коліту
}

Досліджено стан слизової оболонки нисхідної ободової кишки щурів за умов дії похідних піролу 5-аміно4-(1,3-бензотіазол-2-іл)-1-(3-метоксифеніл)-1,2-дигідро-3Н-пірол-3-ону (Д1) та 1-(4-Cl-бензил)-3-Cl-4-(CF феніламіно)-1Н-пірол-2,5-діон (МI-1), які характеризуються цитостатичною дією, протизапальними властивостями та не пошкоджують слизову оболонку товстої кишки щурів, про що свідчать отримані дані. Установлено, що MI-1 за умов індукованого експериментального коліту виявляє максимальний протизапальний та захисний ефект щодо слизової оболонки низхідної ободової кишки, тоді й захисна дія Д1 та комбінації Д1 і МІ-1 є значно слабшими. Сумісна дія похідних піролу із традиційним протизапальним засобом - преднізолоном відносно слизової оболонки низхідної ободової кишки при застосуванні за умов коліту є слабшою, порівняно 3 преднізолоном i, зокрема, із досліджуваними похідними піролу. При цьому в ряду преднізолон+МI-1, преднізолон+Д1, преднізолон+Д1+М1 протизапальна активність спадає.

Ключові слова: експериментальний коліт, преднізолон, похідні піролу, слизова оболонка низхідної ободової кишка.

Постановка наукової проблеми та її значення. Запальні захворювання кишечнику (ЗЗК), до яких традиційно належить виразковий коліт (ВК), - одна 3 найбільш серйозних проблем сучасної гастроентерології, що обумовлено їх постійно зростаючою поширеністю у всьому світі, хронічним, неухильно прогресуючим перебігом та ризиком кишкових і позакишкових ускладнень [1, 2]. Незважаючи на численні дослідження, етіологія ВК достеменно невідома. Серед їі причин називають спадковість, алергічні реакції, харчування, тривале застосування нестероїдних протизапальних засобів тощо [2, 3]. Наслідком хронічної форми ВК у більшості випадків може бути розвиток злоякісних новоутворень - колоректального раку $[1 ; 4 ; 5]$.

Перспективним здобутком для лікування злоякісних новоутворень є таргетні препарати, що вибірково діють на молекулярні мішені - ключові молекули сигнальних шляхів, які відповідають за передачу проліферативного сигналу, процеси апоптозу, контроль клітинного циклу та ін. Сьогодні вже доведено, що вказані засоби характеризуються високою протипухлинною активністю й значно меншою токсичністю, порівняно 3 класичними цитостатиками, а також мають протизапальні властивості $[4 ; 6 ; 7 ; 8]$.

До препаратів цього класу відносять похідні піролу 1-(4-Сl-бензил)-3-Cl-4-(CF 3 -феніламіно)-1Нпірол-2,5-діон (MI-1) та 5-аміно-4-(1,3-бензотіазол-2-іл)-1-(3-метоксифеніл)-1,2-дигідро-3Н-пірол-3он (Д1), синтезовані методом in silico дизайну Науково-виробничим хіміко-біологічним центром Київського національного університету імені Тараса Шевченка [9], що мають виражену цитостатичну дію, показану на лініях трансформованих [10] і ракових клітин [11-14]. Також установлено, що ці сполуки сприяють зменшенню запалення, що супроводжує розвиток раку, та оксидативного стресу [15, 16]. Отже, дослідження впливу похідних піролу на розвиток експериментального коліту є перспективним

(С Сна М., Кузнєцова Г., Дзюбенко Н., Рибальченко В., 2015 
iз погляду можливості застосування цих сполук за умов передракових станів для попередження злоякісного переродження клітин слизової оболонки товстої кишки.

Мета дослідження - вивчення впливу похідних піролу на стан слизової оболонки низхідної ободової кишки щурів за умов експериментального коліту, порівняно з традиційним протизапальним препаратом на основі глюкокортикоїдів - преднізолоном.

Матеріали та методи дослідження. Дослідження проведено відповідно до загальноприйнятих біоетичних норм гуманного поводження 3 лабораторними тваринами згідно 3 національними та міжнародними положеннями стосовно проведення експериментальних робіт («Свропейської конвенції про захист хребетних тварин, які використовуються для дослідних і наукових цілей» (Страсбург, 1986); «Загальних етичних принципів експериментів на тваринах», ухвалених Першим національним конгресом біоетики (Київ, 2001).

Експерименти проводили протягом двох тижнів на 60 білих лабораторних нелінійних щурахсамцях із початковою масою 213 г. Тварин утримували на стандартному раціоні віварію. Модель експериментального виразкового коліту відтворювали 2-кратним ректальним уведенням 1 мл $4 \%$ розчину оцтової кислоти з інтервалом в один тиждень. Попередньо тваринам очищали товсту кишку за допомогою ректального уведення 2-3 мл фіз. розчину з наступним масажем нижньої частини черева для полегшення випорожнення за 10-15 хв до уведення оцтової кислоти. МI-1 у дозі 2,7 мг/кг та Д1 у дозі 2,3 мг/кг уводили щоденно інтрагастрально, розчиненими в соняшниковій олії, що містить 15 \% ДМСО (усього 0,1 мл). Преднізолон (ПрАТ «БІОФАРМА», Україна, розчин для ін’єкції) у дозі 0,7 мг/кг $[17,18]$ уводили щоденно внутрішньоочеревинно розведеним у фізіологічному розчині. Перше уведення сполук здійснювали через 2 год після першого уведення оцтової кислоти. Контрольні тварини отримували відповідні розчинники. Тварин розділено на дев’ ять груп (n=7): I контроль, II - експериментальний коліт, III - коліт +Д1, IV - коліт + MI-1, V - коліт + Д1 + MI-1, VI - коліт + Преднізолон, VII - коліт + Преднізолон + Д1, VIII - коліт + Преднізолон + MI-1, IX - коліт + Преднізолон + Д1 + MI-1. Щурів умертвляли через добу після останнього уведення речовин за допомогою інгаляції $\mathrm{CO}_{2}$ та наступною цервікальною дислокацією.

На макроскопічному рівні оцінювали стан слизової оболонки низхідної ободової кишки за 10-бальною шкалою згідно з Şehirli та ін. (2009) [19]. Для гістологічних досліджень брали сегменти товстої кишки (низхідна ободова кишка), які фіксували в 10 \% нейтральному сольовому формаліні, виготовляли парафінові зрізи та забарвлювали гематоксиліном-еозином за стандартною методикою [20]. Препарати аналізували на світлооптичному рівні за допомогою мікроскопа Olympus BX41 (Olympus Europe $\mathrm{GmbH}$, Японія), кольорові мікрофотографії отримували за допомогою цифрової фотокамери Olympus C-5050 Zoom (Olympus Europe GmbH, Японія) та вказаного мікроскопа. Оцінювали загальний стан слизової оболонки низхідної ободової кишки, ступінь запального процесу оцінювали за 11-бальною шкалою згідно з Appleyard and Wallace, 1995 [21]. Морфометричні дослідження проводили за допомогою програми WCIF ImageJ. Вимірювали товщину слизової оболонки, глибину й ширину крипт, висоту колоноцитів, площу поперечного перетину келихоподібних клітин та ядер колоноцитів. Підраховували відносну кількість біфуркаційних крипт, відносну кількість келихоподібних клітин і мітотичний індекс клітин у криптах.

Статистичну обробку експериментальних даних здійснювали методами варіаційної статистики [22] за допомогою пакета програм SPSS 16.0: дані перевіряли на нормальність розподілу за допомогою Z-тесту Колмогорова-Смирнова, міжгрупові порівняння виконували методом однофакторного дисперсійного аналізу (ANOVA) з використанням для апостеріорних множинних порівнянь F-критерію Фішера, а також за допомогою U-тесту Манна-Уїтні. Різниця між значеннями порівнюваних показників вважалася вірогідною при $\mathrm{p} \leq 0,05$.

Виклад основного матеріалу й обгрунтування отриманих результатів дослідження. У щурів контрольної групи слизова оболонка низхідної ободової кишки має типову гістологічну будову, що характерна для цього виду піддослідних тварин, без ознак патологічних процесів. Морфометричні дані представлено в табл. 2.

Вплив індукованого коліту на слизову оболонку низхідної ободової кишки щурів

За умов індукованого коліту виявлено незначні тріщини та виразкоутворення на поверхні слизової оболонки, також простежено ознаки запалення (гіперемія, міграція лейкоцитів), зміни судинного русла, (діапедезні крововиливи та кровостази), а також десквамацію поверхового епітелію 
(табл. 1). Порівняно 3 контролем, вірогідних змін морфометричних показників не виявлено (табл. 2; 3), що підтверджує відсутність атрофічних змін у клітинах слизової оболонки. Згідно 3 літературними даними, ці явища свідчать про розвиток коліту без атрофії [1, с. 23].

Вплив преднізолону на слизову оболонку низхідної кишки щурів при виразковому коліті

При макроскопічному огляді пошкоджень кишки тварин цієї групи не простежено, а при мікроспопічному зникала десквамація поверхового епітелію слизової оболонки, хоча помітні ознаки запалення у вигляді незначної інфільтрації лімфоцитами та спазму кишкової стінки (табл. 1). Порівняно 3 контролем, вірогідних змін морфометричних показників не виявлено, проте відносно групи коліту знижувалася кількість келихоподібних клітин на 13,8 \%, що вказує на зниження кількості продукованого слизу (табл. 3).

Отриманні результати свідчать про зниження запального процесу та відновлення цілісності слизової оболонки товстої кишки.

Вплив MI-1 на слизову оболонку низхідної кишки щурів при експериментальному коліті

На макроскопічному рівні пошкодження кишки не простежували. При гістологічному дослідженні зникали десквамація поверхового епітелію й ознаки спазму кишкової стінки (потовщення м'язового шару), зменшувалося запалення слизової оболонки, проте виявлено деякі порушення судинного русла (еритростаз, незначні діапедезні крововиливи) (табл. 1). Показники морфометрії після лікування MI-1 наближалися до контрольної групи, а порівняно з групою коліт, зростала площа ядер колоноцитів на 18,9 \%, що засвідчує посилення функціональної активності колоноцитів (табл. 2).

Згідно з отриманними даними, MI-1 пригнічує запальний процес і цілісність слизової оболонки товстої кишки.

Вплив Д1 на слизову оболонку низхідної кишки щурів при експериментальному коліті

При макроскопічному огляді пошкодження кишки не простежено. На мікрорівні виявляли зникнення десквамації епітелію, відсутність спазму кишкової стінки, проте помітні зміни слизової оболонки у вигляді запального процесу, порушення мікроциркуляторного русла (гіперемія) та розростання лімфатичної тканини, тобто зміни, подібні до таких при MI-1, але дещо більш виражені [1, с. 27] (табл. 1). Аналізуючи дані морфометрії, простежили вірогідне зростання товщини слизової оболонки на 31,8 \% (табл. 2), порівняно з показниками контрольної групи, що може бути пов’язано 3 активацією захисних процесів у слизовій оболонці ободової кишки.

Отже, Д1 сприяв відновленню цілісності поверхового епітелію слизової оболонки товстої кишки та зменшенню рівня запалення.

Сумісна дія МI-1+Д1 на слизову оболонку низхідної кишки щурів при експериментальному коліті

На макрорівні виявлено запальні зміни слизової оболонки в цій групі, проте на мікрорівні простежено ознаки запального процесу, дифузного злущення поверхового епітелію, гіперемії та стазу крові в капілярах, а також ознаки спазму кишкової стінки (табл. 1). Аналізуючи дані морфометрії, помітили вірогідне зростання товщини слизової оболонки на $34,4 \%$, що засвідчує активацію компенсаторних процесів і зменшення мітотичного індексу клітин крипт на 32,6 \% (табл. 2; 3). Це означає пригнічення проліферативної активності клітин, зумовлене цитостатичними властивостями похідних піролу [9].

Отже, за умов сумісної дії Д1 та МI-1 макроскопічні ознаки коліту зникають, проте порушення капілярного кровотоку зберігається.

Таблицяя 1

Макро- та мікроскопічні зміни низхідної ободової кишки щурів при дії похідних піролу та преднізолону за умов виразкового коліту

\begin{tabular}{|l|c|c|}
\hline \multicolumn{1}{|c|}{$\mathbf{1}$} & $\begin{array}{c}\text { Макроскопічні зміни (ступінь } \\
\text { пошкодження кишки, балів) }\end{array}$ & $\begin{array}{c}\text { Мікроскопічні зміни (інтенсивність } \\
\text { запального процесу, = балів) }\end{array}$ \\
\hline \multicolumn{1}{|c|}{ Контроль } & $\mathbf{2}$ & $\mathbf{3}$ \\
\hline Коліт & 0 & 0 \\
\hline Коліт П* & $5^{\bullet}$ & 3 \\
\hline Коліт МІ-1 & 0 & 1 \\
\hline Коліт Д1 & 0 & 2 \\
\hline Коліт МІ-1+Д1 & 0 & 2 \\
\hline
\end{tabular}


РОЗДІЛ ІІІ. Фізіологія людини і тварин. 12, 2015

Закінчення табличі 1

\begin{tabular}{|l|l|l|}
\hline \multicolumn{1}{|c|}{$\mathbf{1}$} & $\mathbf{2}$ & $\mathbf{3}$ \\
\hline Коліт $\Pi^{*}+\mathrm{MI}-1$ & 0 & 2 \\
\hline Коліт $\Pi^{*}+Д 1$ & 0 & 4 \\
\hline Коліт $\Pi^{*}+\mathrm{MI}-1+Д 1$ & 0 & 4 \\
\hline
\end{tabular}

Примітка. • - 0 - відсутність пошкоджень; 1 - локалізована гіперемія, без виразки; 2 - виразка без гіперемії або потовщення стінки кишки; 3 - виразка із запаленням в одному місці; 4 - два або більше сайтів виразки / запалення; 5 великі сайти пошкодження завдовжки понад 1 см по всій довжині товстої кишки; 6-10 - пошкодження завдовжки понад 2 см по довжині товстої кишки, де збільшується оцінка по кожному додатковому 1 см ушкодження [22]. • 1 - утрата архітектури слизових оболонок (оцінка 0-3); 2 - клітинна інфільтрація (0-3); 3 м'язове потовщення (0-3); 4 - формування крипт абсцесів (0-1); 5 - виснаження келихоподібних клітин (0-1) [24].

Сумісна дія преднізолон+МІ-1на слизову оболонку низхідної кишки щурів при експериментальному коліті

При макроскопічному аналізі препаратів цієї групи відмінностей від контролю не простежено, а при гістологічному дослідженні в слизовій оболонці низхідної ободової кишки помітні ознаки запалення, інколи - зміни судинного русла (розширення та кровонаповнення), хоча десквамація поверхового епітелію та ознаки спазму кишкової стінки зникали (табл. 1).

Отже, комбінація преднізолон+МI-1 за умов коліту пригнічує запальний процес, сприяє відновленню цілісності слизової оболонки товстої кишки й спричиняє зниження продукції слизу.

Таблиия 2

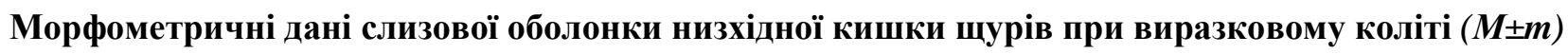

\begin{tabular}{|c|c|c|c|c|c|c|}
\hline$\stackrel{\vec{t}}{\stackrel{t}{U}}$ & 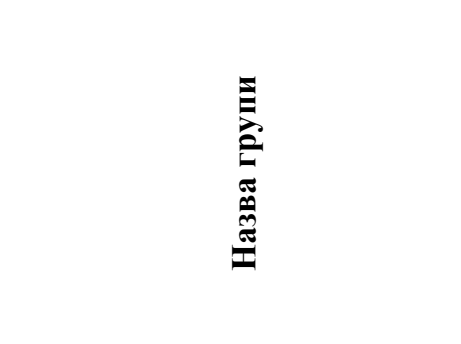 & 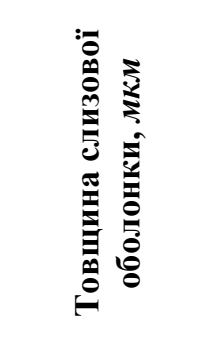 & 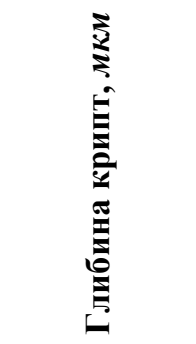 & 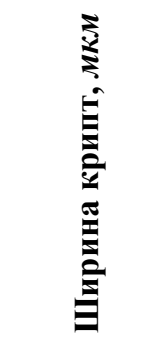 & 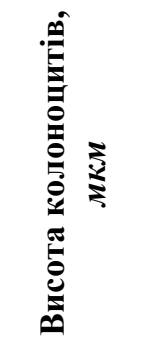 & 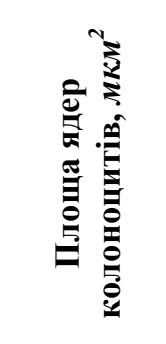 \\
\hline \multirow{9}{*}{$\sum_{\text {E }}^{E}$} & Контроль & $588,5 \pm 93,8$ & $252,2 \pm 26,0$ & $31,5 \pm 4,8$ & $17,2 \pm 3,6$ & $22,7 \pm 4,8$ \\
\hline & Коліт & $648,7 \pm 103,6$ & $265,2 \pm 36,4$ & $30,7 \pm 4,4$ & $17,4 \pm 2,6$ & $22,0 \pm 4,2$ \\
\hline & Коліт + Преднізолон & $651,5 \pm 129,4$ & $274,7 \pm 30,8$ & $28,1 \pm 4,8$ & $16,4 \pm 2,4$ & $23,9 \pm 1,6$ \\
\hline & Коліт + МІ-1 & $667,5 \pm 133,6$ & $233,8 \pm 23,4$ & $30,2 \pm 3,4$ & $16,0 \pm 2,2$ & $27,0 \pm 4,4 ®$ \\
\hline & Коліт + Д1 & $776,0 \pm 87,4^{*}$ & $285,6 \pm 34,0 \diamond$ & $28,2 \pm 3,6$ & $14,6 \pm 2,6$ & $23,4 \pm 2,4$ \\
\hline & Коліт + МІ-1 + Д1 & $791,0 \pm 115,2 *$ & $253,0 \pm 53,6$ & $27,1 \pm 4,2$ & $17,2 \pm 8,8$ & $21,4 \pm 4,4$ \\
\hline & Коліт + Преднізолон + МI-1 & $698,0 \pm 130,2 \#$ & $275,4 \pm 40,0 \#$ & $30,0 \pm 4,2$ & $16,8 \pm 0,2$ & $25,8 \pm 0,4 \AA$ \\
\hline & Коліт + Преднізолон + Д1 & $625,1 \pm 74,6$ & $274,8 \pm 45,8$ & $30,5 \pm 2,8$ & $16,9 \pm 1,8$ & $27,3 \pm 1,6$ \\
\hline & Коліт + Преднізолон+МІ-1+Д1 & $706,1 \pm 92,0$ & $267,7 \pm 35,4$ & $25,5 \pm 1,8 *$ & $16,2 \pm 1,6$ & $26,9 \pm 1,2 \AA$ \\
\hline
\end{tabular}

Примітка. *-p $\leq 0,05$ порівняно з контролем, ${ }^{\circledR}-\mathrm{p} \leq 0,05$ порівняно з групою коліт, \# - $\mathrm{p} \leq 0,05$ порівняно 3 групою коліт+преднізолон. коліті

Сумісний вплив преднізолону+Д1 на слизову оболонку низхідної кишки щурів при експериментальному

На макроскопічному рівні пошкодження кишки не простежено, а при гістологічному описі в слизовій оболонці низхідної кишки зникала десквамація поверхового епітелію та ознаки спазму кишкової стінки, проте помітні ознаки запального процесу у вигляді судинних порушень (розширення і їх кровонаповнення) (табл. 1). Морфометричні показники слизової оболонки вірогідно не відрізнялися від контрольної групи (табл. 2, 3).

Отже, комбінація преднізолон+Д1 пригнічує запальний процес і сприяє відновленню цілісності слизової оболонки товстої кишки. 
Стан келихоподібних клітин та мітотичного індексу низхідної кишки щурів при виразковому коліті $(\mathrm{M} \pm \mathbf{m})$

\begin{tabular}{|c|c|c|c|c|c|}
\hline 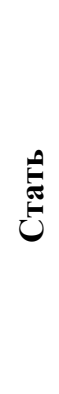 & 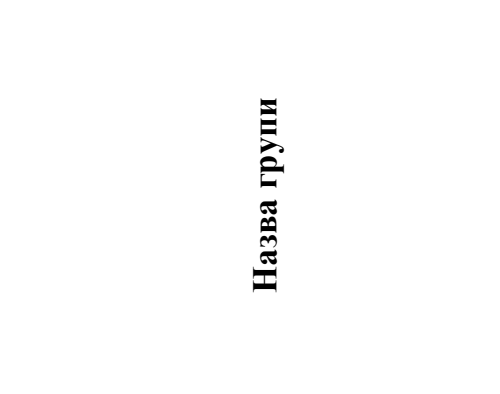 & 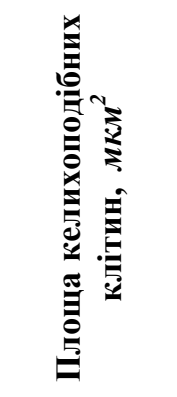 & 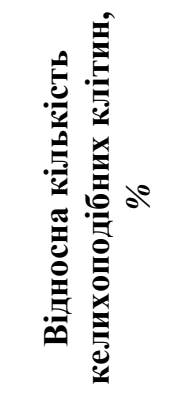 & 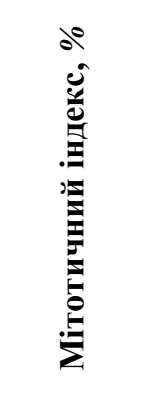 & 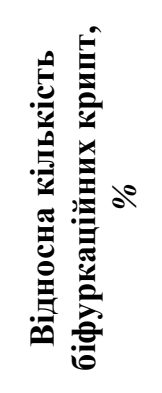 \\
\hline \multirow{9}{*}{ 踥 } & Контроль & $82,1 \pm 10,2$ & $26,7 \pm 3,2$ & $5,2 \pm 0,8$ & $5,7 \pm 2,6$ \\
\hline & Коліт & $69,4 \pm 18,0$ & $28,8 \pm 1,4$ & $5,0 \pm 1,4$ & $7,0 \pm 1,2$ \\
\hline & Коліт + Преднізолон & $65,2 \pm 14,0$ & $23,0 \pm 3,0 \AA$ & $4,6 \pm 1,2$ & $6,4 \pm 1,4$ \\
\hline & Коліт + МІ-1 & $71,9 \pm 8,4$ & $27,5 \pm 3,8 \circledast \#$ & $5,1 \pm 0,6$ & $3,2 \pm 1,0 ® \#$ \\
\hline & Коліт + Д1 & $75,3 \pm 21,8$ & $26,5 \pm 3,4$ & $4,1 \pm 0,8$ & $7,1 \pm 0,8$ \\
\hline & Коліт + MI-1 + Д1 & $70,6 \pm 21,6 \#$ & $28,0 \pm 1,2$ & $3,5 \pm 0,8^{*}$ & $5,0 \pm 2,4$ \\
\hline & Коліт + Преднізолон + MI-1 & $71,7 \pm 29,0 \#$ & $27,2 \pm 3,4 \circledast$ & $6,7 \pm 1,6$ & $6,0 \pm 2,4$ \\
\hline & Коліт + Преднізолон + Д1 & $57,7 \pm 9,4 *$ & $23,3 \pm 2,8$ & $5,3 \pm 1,0 \#$ & $7,5 \pm 1,6^{*}$ \\
\hline & Коліт + Преднізолон+МІ-1+Д1 & $73,4 \pm 19,4$ & $25,5 \pm 1,4$ & $5,6 \pm 1,0$ & $5,3 \pm 2,0$ \\
\hline
\end{tabular}

Примітка. *-p $\leq 0,05$ порівняно з контролем, ${ }^{\circledR}-p \leq 0,05$ порівняно з групою коліт, \# - $\leq \leq 0,05$ порівняно з групою коліт+преднізолон. коліті

Сумісна дія преднізолон+МI-1+Д1 на слизову оболонку низхідної кишки иурів при експериментальному

При макроскопічному дослідженні пошкодження кишки не виявлено, а при гістологічному дослідженні зникала десквамація епітелію й спазм кишкової стінки, проте простежено ознаки запального процесу слизової оболонки у вигляді набряку, порушень капілярного кровотоку (розширення й підвищеного кровонаповнення) (табл. 1). Аналізі даних морфометрії показав вірогідне зменшення ширини крипт на 19 \% (табл. 2), що може свідчити про «здавлювання» крипт набряклою стромою, а порівняно з групою коліту, зростала площа ядер колоноцитів на 18,5 \% (табл. 2), що свідчить про посилення їхньої функціональної активності.

Отже, Преднізолон із похідним піролу за умов експериментального коліту сприяє зменшенню запалення та відновленню цілісності слизової оболонки товстої кишки.

Висновки й перспективи подальших досліджень. Похідне піролу MI-1 за умов індукованого коліту виявляє максимальний протизапальний та захисний ефект щодо слизової оболонки низхідної ободової кишки, тоді як захисна дія Д1 і комбінації Д1 та МІ-1 значно слабша. Сумісна дія похідних піролу з традиційним протизапальним засобом - преднізолоном - відносно слизової оболонки низхідної ободової кишки при застосуванні за умов коліту є слабшою, порівняно і з преднізолоном, і з досліджуваними похідними піролу окремо. При цьому в ряду преднізолон+МI-1, преднізолон+Д1, преднізолон+Д1+М1 протизапальна активність спадає.

\section{Джерела та література}

1. Воробьев Г. И. Неспецифические воспалительные заболевания кишечника / Г. И. Воробьев, И. Л. Халиф. - М. : Миклош, 2008. - 400c.

2. Kaser A. Inflammatory Bowel Disease / A. Kaser, S. Zeissig, R. Blumberg // Annu. Immunol. - 2010. - Vol. 28. P. 573-621.

3. Daniel K. Podolsky Inflamatory bowel disease / K. Daniel // New Eng. J. Med. - 2002. - 347, № 6. - P. 417-429.

4. Xie J. Cancer in inflammatory bowel disease / J. Xie, S. H. Itzkowitz // World J Gastroenterol. - Jan 21. 2008. - 14(3). - P. 378-389.

5. Ullman T. A. Intestinal inflammation and cancer / T. A. Ullman, S. H. Itzkowitz // Gastroenterology. - 2011. May. - 140(6). - P. 1807-16. 
6. Имянитов Е. Н. Общие представления о таргентной терапии / Е. Н. Имянитов // Практ. онкология. 2010. - T. 11, № 3. - C. 123-130.

7. Tsai C.-J. The molecular basis of targeting protein kinases in cancer therapeutics / C.-J. Tsai, R. Nussinov // Seminars in Cancer Biology. - 2013. - Vol. 23, I. 4. - P. 235-242.

8. Del Prete A. Molecular pathways in cancer-related inflammation. / A. Del Prete, P. Allavena, G. Santoro et al. // Biochemia Medica. - 2011. - 21(3). - P. 264-275.

9. Пат. на корисну модель № 22204 (UA), Аб1К31/40. Сполука 1,4-заміщених 5-аміно-1,2-дигідропірол-3-онів, що має протиракову активність / Г. Г. Дубініна, Ю. М. Воловенко; заявник і власник Г. Г. Дубінінна, Ю. М. Воловенко - № u200601855; заявл. 21.02.2006; опубл. 25.04.2007 / Бюлл. - № 5.

10. Nalini N. Chemopreventive efficacy of hesperetin (citrus flavonone) against 1,2-dimethylhydrazine-induced rat colon carcinogenesis / N. Nalini, S. Aranganathan, J. Kabalimurthy // Toxicol. Mech. Methods. - 2012. 22(5). - P. 397-408.

11. Garmanchuk L. V. MI1 - derivative of maleimide inhibits cell cycle progression in tumor cells of epithelial origin / L. V. Garmanchuk, V. K. Ribalchenko, L. I. Ostapchenko [et al.] // Biopolymers and Cell. - 2013. Vol. 29, № 1. - P. 70-74.

12. Kuznietsova H. M. Impact of dihydropyrrol derivative in the normal colonic mucosa of DMH-induced colon cancer rats compared with 5-fluorouracil / H. M. Kuznietsova, O. V. Ogloblya, V. K. Rybalchenko // Experimental Oncology. - 2013. - Vol. 5, № 1. - P. 25-29.

13. Бабута О. М. Гістологічна характеристика слизової оболонки сліпої кишки щурів після впливу МІ-1 та 5-фторурацилу при хемоіндукованому канцерогенезі / О. М. Бабута, О. В. Линчак, В. К. Рибальченко // Вісник проблем біології і медицини. - 2013. - Вип. 3, т. 1 (102). - С. 31-35.

14. Линчак О. В. Морфофункціональний стан органів шлунково-кишкового тракту після впливу похідного малеіміду МІ-1 протягом місяця / О. В. Линчак, Г. В. Островська, В. К. Рибальченко [та ін.] // Сучасні проблеми токсикології. - 2011. - Т. 2, № 1. - С. 52-55.

15. Кузнєцова Г. М. Вплив похідних дигідропіролу та малеіміду на стан печінки і товстої кишки щурів у нормі та в умовах індукованого диметилгідразином колоректального раку / Г. М. Кузнєцова, О. В. Линчак, В. К. Рибальченко [та ін.] // Укр. біохім. журн. - 2013. - Т. 85, № 3. - С. 74-84.

16. Кузнєцова Г. М. Вплив цитостатика похідного дигідропіролу на слизову оболонку кишечника щурів на тлі оксидативного стресу / Г. М. Кузнєцова, А. Т. Воловненко, Г. В. Островська [та ін.] // Доповіді НАН України. - 2012. - № 2. - С. 174-179.

17. Терапевтическая фармакология / [Ф. М. Абдуева, О. Ю. Бычкова, И. А. Бондаренко и др.] ; под общей редакцией Н. И. Яблучанского и В. Н. Савченко. - Харьков : ХНУ им. В. Н. Каразина, 2011. - 483 с.

18. Машковский М. Д. Лекарственные средства / М. Д. Машковский. - 15-е изд., перераб., испр. и доп. М. : ООО «Издательство “Новая Волна"», 2005. - 1200 с. : ил.

19. Ahmet Özer Şehirli Protective effects of alfa-lipoic acid against oxidative injury in TNBS-induced colitis. / Ahmet Özer Şehirli, Elif Tathdede, Meral Yüksel, Şule Çetinel, Can Erzik, Berrak Yeğen, Göksel Şener // Erciyes Tip Dergisi (Erciyes Medical Journal). - V. 31 (1). - 2009. - P. 015-026.

20. Горальський Л. П. Основи гістологічної техніки і морфо-функціональні методи досліджень у нормі та при патології / Л. П. Горальський, В. Т. Хомич, О. І. Кононський. - Житомир : Полісся, 2005. - 288 с.

21. Appleyard C. B. (1995). Reactivation of hapteninduced colitis and its prevention by anti-inflammatory drugs / C. B. Appleyard and J. L. Wallace // Am J Physiol. - 269. - G119-G125.

22. Сергиенко В. И. Математическая статистика в клинических исследованиях / В. И. Сергиенко, И. Б. Бондарева. - М. : Гэотар Медицина, 2006. - 304 с.

23. Струков А. И. Патологическая анатомия : учебник / А. И. Струков, В. В. Серов. - 5-е изд., стер. - М. : Литтерра, 2010. - 848 с. : ил.

Ена Марина, Кузнецова Галина, Дзюбенко Наталия, Рыбальченко Владимир. Влияние производных пирролов на слизистую оболочку толстой кишки крыс по сравнению с глюкокортикоидными препаратами в условиях развития экспериментального колита. Исследовано состояние слизистой оболочки нисходящей ободочной кишки крыс в условиях действия производных пирола 1-(4-Cl-бензил)-3-Cl-4-(CF 3 -фениламино)1Н-пирол-2,5-диону (МИ-1) и 5-амино-4-(1,3-бензотиазол-2-ил)-1-(3-метоксифенил)-1,2-дигидро-3Н-пирол-3ону (Д1), характеризующихся цитостатическим действием, противовоспалительными свойствами, отсутсвием повреждения толстого кишечника крыс, о чем свидетельствуют данные микроскопических исследований. Установлено, что МИ-1 при индуцированном экспериментальном колите проявляет максимальный противовоспалительный и защитный эффект в отношении слизистой оболочки нисходящей ободочной кишки, тогда как защитное действие Д1 и комбинации Д1 и МИ-1 значительно слабее. Совместное действие производных пиррола с традиционным противовоспалительным средством - преднизолоном относительно слизистой оболочки нисходящей ободочной кишки при применении в условиях колита является более слабым по сравнению 
как с преднизолоном, так и с исследуемыми производными пиррола отдельно. При этом в ряду преднизолон+МИ-1, преднизолон+Д1, преднизолон+Д1+МИ-1 противовоспалительная активность падает.

Ключевые слова: экспериментальный колит, преднизолон, производные пиррола, слизистая оболочка нисходящей ободочной кишки.

Yena Maryna, Kuznietsova Halyna, Dzybenko Natalija, Rybalchenko Volodumyr. Pyrrole Derivatives' Effects on rat Colon Mucosa Compared with Glucocorticoid Drugs Under Experimental Colitis. The influence of the pyrrole derivative 1-(4-Cl-benzyl)-3-Cl-4- $\left(\mathrm{CF}_{3}\right.$-phenylamino)-1H-pyrrol-2,5-dione (MI-1) and 5-amino-4-(1,3-benzothyazol-2yl)-1-(3-methoxyphenyl)-1,2-dihydro-3H-pyrrol-3-one (D1) on rat colon mucosa was investigated. Cytostatic effects, inflammatory properties and safety for rat large intestine, have been shown in previous experiments as evidenced by microscopic studies. MI-1 under induction of experimental colitis revealed the maximum inflammatory and protective effect on the descending colon mucosa whereas protective effects of D1 and D1 combination with MI-1 were much weaker.

Antiinflammatory effects of pyrrole derivatives' combinations with reference drug - prednisolone, were weaker compared to prednisolone, D1, MI-1 ones separately. Wherein antiinflammatory properties falled off due prendnisolone+MI-1, prednisolone+D1, prednisolone+D1+MI-1 sequence.

Key words: experimental colitis, prednisolone, pyrrole derivative, mucosa descending colon.

Стаття надійшла до редколегії 28.01.2015 p.

УДК: $612.821612 .8: 616.8$

\section{Олександр Журавльов, Людмила Гошко, Лілія Бурбан}

\section{Аналіз інтенсивності коркової електричної активності в тета-діапазоні ЕЕГ за умов формування фазичних емоцій різної валентності залежно від статі досліджуваних}

У статті наведено результати дослідження коркової електричної активності в тета-діапазоні ЕЕГ при формуванні фазичних емоцій різного знака залежно від фактора статі. Показано наявність відмінних рис у загальній організації коркового електрогенезу в чоловіків та жінок при індукуванні фазичних емоцій, які полягають у більш генералізованому зростанні інтенсивності тета-активності в досліджуваних жіночої статі при використанні відеокадрів, що формують негативні емоції.

Ключові слова: фазичні емоції, електрична активність кори головного мозку, тета-активність.

Постановка наукової проблеми та ії значення. Результати нейрофізіологічних досліджень останніх років стосовно переживання емоцій свідчать як про специфічність, так і про відносну універсальність топографічно розділених нейронних систем, що опосередковують механізми генерації розгорнутої емоційної реакції [6]. Тим часом питання про віддзеркалення емоцій у біоелектричній активності мозку багато в чому залишається нез'ясованим.

Аналіз досліджень цієї проблеми. На сьогодні існує значна кількість наукових джерел із питань емоційної організації поведінки людини та її особливостей, однак серед них варто відзначити обмежену кількість комплексних психо- та нейрофізіологічних досліджень, у яких би аналізувалися дві чи більше емоції одного знака [3], а аналіз досліджень окремих дискретних емоцій із допомогою ЕЕГ, позитронно-емісійної томографії й функціонального магнітного резонансу не дає змоги скласти їх коркове віддзеркалення, ураховуючи істотні відмінності в методичних підходах.

Отже, мета дослідження - вивчення особливостей коркової нейродинамічної активності при індукції фазичних емоцій різного знака.

У процесі роботи проведено обстеження 200 осіб (100 жінок та 100 чоловіків) віком 18-20 років, здорових, за даними психоневрологічного та соматичного обстеження (медична картка 086/y), праворуких, за самооцінкою й спеціально розробленими мануальними тестами [1]. Усі досліджувані -

( Журавльов О., Гошко Л., Бурбан Л., 2015 